Article

\title{
Surviving the "Sexplosion": Christianity Today and Evangelical Sexual Ethics in the Long 1960s
}

\author{
Aaron Pattillo-Lunt (iD
}

check for

updates

Citation: Pattillo-Lunt, Aaron. 2021. Surviving the "Sexplosion": Christianity Today and Evangelical Sexual Ethics in the Long 1960s.

Religions 12: 112. https://doi.org/ $10.3390 /$ rel12020112

Academic Editors: Randall Balmer and Edward Blum

Received: 12 January 2021

Accepted: 5 February 2021

Published: 10 February 2021

Publisher's Note: MDPI stays neutral with regard to jurisdictional claims in published maps and institutional affiliations.

Copyright: (C) 2021 by the author. Licensee MDPI, Basel, Switzerland. This article is an open access article distributed under the terms and conditions of the Creative Commons Attribution (CC BY) license (https:// creativecommons.org/licenses/by/ $4.0 /)$.
History Department, University of North Carolina, Chapel Hill, NC 27599, USA; apattillolunt@unc.edu

\begin{abstract}
This paper examines how the editors and contributors to Christianity Today $(C T)$ called for an evangelical sexual ethics in the 1960s. Editors and contributors alike were concerned that the supposed sexual immorality on college campuses, the liberalization of obscenity laws, the approval and sale of the birth control, and secular sex education programs threatened the United States' social health. They believed that evangelicals needed to learn how to talk about sex, and this belief resulted in the development of conservative Protestant sex manuals by the middle of the 1970s. Overall, talk about sex in the pages of $C T$ demonstrates that evangelicals are neither anti-sex nor traditionalists. They instead forged a new sexual ethic in response to the historical events and developments of the 1960s.
\end{abstract}

Keywords: evangelicalism; the long 1960s; the sexual revolution; sexuality; religion; conservatism; Christianity Today

\section{Introduction}

Evangelicals talk about sex a lot, and scholars have tended to see religious conservatives' talk about sex as reactionary and emblematic of "traditionalism" (Griffith 2017; Irvine 2002). Yet, if evangelicals were defending "tradition," they also worked to redefine it in the late 1950s and throughout the 1960s. "Tradition," as conservative Christian activists understood it, was linked to the post-WWII economic boom. Families that benefitted from government programs like the GI Bill were able to purchase homes and build a life in suburban spaces. Conservative Christians touted this new reality as representative of "tradition" writ large. ${ }^{1}$ Their embrace of family values politics promoted the idea that the white, middle-class family with a father who worked and a mother who stayed at home was the "traditional" family without acknowledging that this recent and idyllic phenomenon was dependent more on one's class and race than on any innate familial characteristics (Self 2012, p. 10; Dowland 2015, pp. 8-12).

To paint conservative Christians generally and evangelicals particularly as "traditionalists" affirms their ahistorical definition of tradition. It also downplays how evangelicals since the 1960s were both resisting what they believed to be a sexual revolution and generating a new sexual ethic centered on a sex positive, though still patriarchal and gendered understanding, of sex. This ethic was accompanied by an increasing conflation between social health and conservative Protestant ideas about sexual morality. In order to understand these developments, I examine how authors in the flagship magazine of evangelicalism in

1 The cult of domesticity and "tradition" that the Christian Right championed was a product of the post-war economic boom in the 1950s and the importance of the home in the Cold War. See the excellent analysis of the Cold War's domestic front in (de Grazia 2005, pp. 416-57). For the idea that conservatives en masse sought a return to the "normative America" of the 1950s (with all of its racial, sexual, and political connotations), see (Hartman 2016, pp. 5-7). Robert Self further describes the Christian Right as championing a version of the family that was "archetypal and prescriptive" in (Self 2012, p. 331). A notable exception to arguments that evangelicals were defenders of tradition can be seen in (DeRogatis 2015, p. 3). 
the United States, Christianity Today (CT), responded to the "sexual revolution" during the long 1960s. ${ }^{2}$

Understanding $C T^{\prime}$ s influence requires a consideration of the tactics used by conservative media outlets more broadly. Historian Nicole Hemmer has demonstrated that mass circulation was not always the aim for conservative media enterprises. Instead, the goal was to affect "public opinion indirectly" by targeting an elite audience that could broadcast conservative ideas through "policy, popular media, and public stances" (Hemmer 2016, p. 36). I contend that the founders of $C T$ employed a similar model. The magazine was headquartered in Washington, D.C., until July of 1977, and this reflected the founders' desire to put $C T$ in proximity with the "strategic centers of national life." ${ }^{3}$ Furthermore, the editors planned to send free copies of $C T$ to pastors throughout the U.S., Canada, and Great Britain and to prominent journalists in D.C. for the first year (Worthen 2014, p. 59). Circulation mattered less than who was reading it.

While $C T^{\prime}$ 's editors may have hoped to speak for and to all evangelicals, there is little doubt that $C T^{\prime}$ s primary audience was white evangelicals. This was certainly the case when $C T$ wrote about sex. The editors opposed interracial marriage because, while they could not "morally object," interracial marriage "may nonetheless be spiritually inexpedient and sociologically inadvisable" ("What of Racial Intermarriage?" 1963). In simple terms, the editors did not believe that children raised in a family headed by white and Black parents would be socially accepted. This editorial also cited a verse used by segregationists and integrationists alike, Acts 17:26, to argue that "God has preserved distinct nations whose social components are often racial," and this called into question any hope that "racial distinctions" could be ended on this side of eternity ("What of Racial Intermarriage?" 1963; Houck and Dixon 2014, pp. 21-22; Dailey 2004, pp. 121-23; Botham 2009, pp. 44, 108-10). The emergent white evangelical sexual ethic, then, was proposed in a magazine that catered to white racists' fears about interracial marriage, and white evangelicals also participated in a broader political effort to pathologize Black families and situate the white nuclear family as normative (Self 2012, pp. 26-32, 339-42). White evangelical racism, therefore, contributed to differences between white evangelicals' and Black conservative Protestants sexual ethics (DeRogatis 2015, pp. 130-49).

Christianity Today is self-consciously "evangelical." This is significant given how difficult it is to determine who is and who is not an evangelical (Kidd 2019; Noll et al. 2019). In other terms, because the founders and current editors of $C T$ say it is an evangelical publication, it is one. This sets it somewhat apart from the host of sex manuals that have been published within conservative Protestantism since the 1970s. Indeed, as Daniel Vaca has demonstrated, "evangelicalism" can serve as a marketing slogan used by publishers to broaden any given "evangelical" book's audience, making it even harder to determine who is and who is not an evangelical, absent a close attention to consumption habits or conservative Protestants' self-identification as such (Vaca 2019, p. 12; Du Mez 2020a).

The dialogic relationship between consumption patterns and evangelical biblical interpretation needs to be more fully considered. In this essay, I accept that people who self-identify as evangelicals are evangelicals. This approach is better than imposing the label on those (like Black conservative Protestants) who, by theological standards, seem like evangelicals but may not self-identify as evangelical (Tisby 2019; Du Mez 2020b). This also means that efforts to understand an "evangelical" viewpoint should pay special attention to the intellectual and social labor of self-consciously evangelical publications, pastors, bloggers, and activists.

As far as defining evangelicalism theologically, I believe biblicism is a key identifier. While other Christians hold the Bible in high esteem, evangelicals' literal, plain reading,

2 For an explanation of "the long 1960s," see (Hall 2008). See also Hall's more expansive consideration of “The Long 1960s" in (Hall 2011). I place "sexual revolution" in quotes here because scholars have challenged the idea that the "sexual revolution" was monolithic and/or revolutionary. See, (Bailey 1994; Bailey 1999).

3 See ("The Evangelical Witness" 1956). In 1977, CT split its offices between D.C. and Carole Stream, IL. See the addresses in the indexes for the 8 July 1977, and 29 July 1977, editions for the official change of address and, thereby, the notice of the magazine's move out of D.C. 
and personal interpretation of the Bible sets them apart. They usually avoid justifying or explaining their actions and beliefs using nonbiblical sources even though their understanding of the Bible is informed (to an extent so great that they rarely admit it) by their consumption of nonbiblical sources like conservative Protestant books, magazines, movies, radio, and television. When it came to talk about sex, a patriarchal reading of the Bible was the norm. This evangelical deference to a patriarchal sexual ethic was developed in sex manuals, but it was also grounded in a particular reading of the Bible. Passages that stressed women's submission to men were foregrounded, and feminist readings of the Bible were dismissed as lacking biblical support. Evangelical patriarchalism, as with the white evangelical racism outlined above, was reinforced with biblical references. All this to say, evangelicals' belief that "the best sex manual is the Bible" indicates the centrality of biblicism in the development of evangelical sexual ethics (DeRogatis 2005, p. 114). Yet, special emphasis still needs to be given to self-identification. I reflect this emphasis by using "conservative Protestant" as a broader social category than "evangelicalism" when I am speaking about material that reaches outside of self-consciously evangelical networks.

My examination of how CT navigated the sexual revolution and its effort to find a new conservative Christian sexual ethic focuses on articles written from 1960 until the middle of the 1970s. During this time period, I give primacy to editorials because they can be seen as representative of the magazine's direction and its editors' goals. ${ }^{4}$ I focus on this period because conservative Christians saw the supposed increase of sexual immorality on college campuses, the liberalization of obscenity laws, and "secular" sex education as creating a sexobsessed culture. In this respect, evangelicals were reactionaries because it was progressive voices and causes that drove debates over sexuality (Griffith 2017). Evangelicals were not, however, merely reactive. In talking about sex, they were productive.

\section{Before Evangelical Sex Manuals}

Historical analyses of when evangelicals began generating a sex positive ethic has tended to focus on sex and marriage manuals, particularly two that were published in the early 1970s: Marabel Morgan's The Total Woman (Morgan 1973) and Tim and Beverly LaHaye's The Act of Marriage (1976). ${ }^{5}$ The Total Woman is usually remembered for its suggestion that women should greet their husbands at the door in sexy costumes and try having sex in a variety of adventurous locations (Morgan 1973, pp. 94-99). Morgan also expressed a comfortability with allowing her children to watch her husband chase her around the home in these costumes (Morgan 1973, pp. 95-96). This allowed her to model for her children the way that a woman was supposed to submit to her husband's desires in marital relationships. In so doing, she spoke frankly and publicly about having sex from a conservative Christian viewpoint without suggesting that men and women were equal partners within marriage.

The LaHayes advanced a similar approach to marriage and sexuality even as they departed from Morgan by speaking in depth about how sex needed to be pleasurable for husbands and wives. ${ }^{6}$ They also delved into technique, offering step-by-step instructions for how to have sex on the wedding night, and they encouraged men to learn how to stimulate their spouse's clitoris (DeRogatis 2015, pp. 48, 50-51). In presenting sex as sacred and mutually pleasurable and detailing how to perform in the bedroom, the LaHayes signaled to a wider audience that evangelicals were not opposed to sex. Indeed, within heterosexual and monogamous marriages, sex was good and enjoyable.

4 Editorials in the time period I explore are not usually attributed to any particular editor. If an article was written by and attributed to an editor of the magazine, I reference them by name in the article and in the in text citations.

5 If members of the Church of Latter Day Saints self-identify as or are included by scholars within evangelicalism, earlier marriage and sex manuals need to be considered. See (Young 2018).

6 Morgan insisted that sex was supposed to be pleasurable for men and women, yet her work suggested that women were to go out of their way to make sure their husbands desires were met, and she said comparatively little about husbands' role in ensuring their wives were sexually satisfied. Morgan would likely argue that, because she was ministering to women, she did not intend to tell men how to engage in sex with their spouses. For an illuminating interview with Morgan in CT on this point, see ("Marabel Morgan: 'Preferring One Another'" 1976). 
Focus on these books remains important because they quickly dispel any notion that evangelicals were anti-sex. Instead, as Amy DeRogatis has argued, evangelicals expertly made the sexual revolution their own (DeRogatis 2015, p. 3). The incredible number of sex manuals published after the 1970s speaks to this fact. Sex manuals themselves, however, tell only half the story. They are the end products of evangelical efforts to address the absence of conservative Protestant sex education programs during and after the 1960s. The editors and contributors to $C T$ were well aware of this absence, and their calls for conservative Protestant responses to the sexual revolution began in earnest in the early 1960s. This concern was fueled by the sexual revolution on secular college campuses, sex education, changes in obscenity laws, and the Food and Drug Administration's (FDA) approval of oral contraceptives. Turning the clock back to the decade before Morgan and the LaHayes wrote their popular marriage and sex manuals reveals the origins of evangelicals' particular concerns about the sexual revolution, and it sheds light on how "morality" is frequently used as a synonym for "sexual morality" within evangelicalism.

At the outset of the 1960s, the editors of CT wondered whether it was possible to maintain an "evangelical advance," and this prompted them to ask: "Do we need a Christian university? ("Evangelical Advance" 1960). In this expansive editorial, the editor meditated on the state of the United States and bemoaned that evangelicals did not seem to care about the life of the mind (at least not enough to fund a Christian university). ${ }^{7}$ This was a problem. Christians students were increasingly studying in "an atmosphere repressive of Christian faith and life," and the "tendency [on secular campuses] is to disregard Christianity as a relevant world-life view" ("Evangelical Advance" 1960). The post-war increase in collegiate enrollments made this problem even more acute. Evangelicals were not merely losing out on a generation of Christian professionals; they were consigning Christian students to an immoral education and ensuring that America would hurtle "over the great falls of secularism" ("Evangelical Advance" 1960). The editor was well aware that liberal arts and private universities were in a moment of crisis nationally, yet they still contended that there was a "staggering need" for a well-respected Christian alternative to secular universities ("Evangelical Advance" 1960).

This conversation was timely. Historian Adam Laats has demonstrated that the post-World War II emergence of "a new sort of fundamentalism" led to a divide within conservative Protestant colleges and universities (Laats 2018, p. 122). University administrators needed to determine whether they would eschew the label "fundamentalist" in favor of the label "evangelical" (Laats 2018, pp. 123-24). In calling for a Christian university that addressed sexual morality from a Christian perspective, $C T^{\prime}$ 's editors suggested that "fundamentalist" universities could not stem the tide of immorality on secular campuses without creatively engaging with secular trends and presenting Christian counterpoints. For the editor, this was only possible if Christian universities hired committed faculty that wrote books that appealed to the academy writ large. Through "corporate conversation, research, and writing," textbooks could be written from a Christian perspective that challenged the "monopoly ... held by secular scholars" ("Evangelical Advance" 1960). The editor also made it clear that existing Christian universities could not have this model "superimposed" on them absent structural changes ("Evangelical Advance" 1960). This call for new universities and a new curriculum that was wide ranging and broadly appealing could not leave out a topic as important as sex. ${ }^{8}$

The editor's lengthy plea for a Christian university appealed to morality in general terms, and it was not immediately clear why the editor felt a university was needed in

7 This editorial's byline is "The Editor." I reflect that singular usage of "editor" when speaking about this editorial.

8 Several prominent Christian universities were founded in the years immediately following this editorial's publication, including Liberty University (1970), Pensacola Christian College (1974), and Regent University (1978). For a brief consideration of the development and growth of Christian universities in these years, see (Laats 2018, p. 216). This did not, however, settle the debate over whether a Christian university of the sort that $C T^{\prime}$ s editors wanted was founded. The publication of Arthur Holmes's The Idea of a Christian College in 1975 (and a second edition published in 1994) indicated that at least a few prominent evangelicals were concerned about the state of Christian higher education well after The Editor made an impassioned plea for a new kind of Christian university. 
that moment. The editorial ended with a significant and revelatory quote from Harvard sociologist Pitirim Sorokin's The American Sex Revolution. Published in 1956, The American Sex Revolution argued that this sex revolution was more impactful than any political or economic revolution (Sorokin 1956, pp. 3-4). The editors of CT were fascinated by Sorokin's arguments, particularly because he elevated marriage as the "noblest and best" expression of love and believed the pursuit of sexual pleasure outside of marriage would lead to "demoralization, social irresponsibility, mental disorders, and crime" (Sorokin 1956, pp. 5-7). The quote $C T$ pulled from The American Sex Revolution spoke about how university professors, many of whom were divorced, were in charge of teaching young people about personal, sexual, and familial relationships. This would produce a society filled with "profligates" ("Evangelical Advance" 1960; Sorokin 1956, p. 44). Calls for a Christian university were, therefore, rooted in a fear that lax sexual morality on college campuses would literally bring the ruin of the United States.

Sorokin must have struck a chord with the editors and writers of CT. From 1957 to 1993, his arguments were used to explain the collapse of a moral society no less than two dozen times, including a favorable review of The American Sex Revolution and two articles written by Sorokin himself (Ockenga 1957). It is not immediately clear why Sorokin chose to write for CT. He was raised and died a member of the Russian Orthodox Church and was not an evangelical. He did believe in the "moral precepts of Christianity" and, as an exile from the Soviet Union, it is possible that he saw $C T$ as an intellectual ally in preventing a drift towards social collapse during the Cold War (Sorokin 1963, pp. 40-41; Sorokin 2017). Sorokin's two articles in the pages of CT detailed his fear that sexual permissiveness was quite literally advertised. Pornography had broken into public life subversively. It was found in "supposedly decent literature and fine arts, in our free press, movies, radio, and television, in our alluring advertising, prosperous economies, and power policies, and even in our modern science, 'rational' philosophy, and 'Fruedanized' religion" (Sorokin 1959). Combined, media productions had created a sex obsessed culture, and Sorokin believed the sex revolution could be abated only if, first, no new world wars began and, second, the "Sensate social order" could be supplanted by a "more spiritual and morally nobler Integral order" (Sorokin 1960).

Sorokin's The American Sex Revolution and his opinion pieces in CT advanced an important thesis-social and political health were dependent on sexual morality. This argument was reproduced in $C T$ as its contributors worked to produce a biblically-rooted spiritual and noble order. It needs to be emphasized that the conflation between social health and sexual health placed a premium on two things. First, sexual morality (as the editors perceived it) mattered more than the general public seemingly thought it did. Second, conservative Protestants needed to teach biblical sexual morality to prevent social collapse. This realization prompted evangelicals to call for a socially restorative sexual ethic.

Sorokin's claim that there was a sex revolution and that the media caused it led to two panel discussions by the editorial staff of $C T$ in 1960 and $1961 .^{9}$ The preface to the first acknowledged that there was a "sex crisis" in America and argued that evangelicals needed to "speak out energetically and earnestly on larger facets of the sex problem" ("Sex in Christian Perspective" 1960). L. Nelson Bell (who, in addition to being an editor for $C T$, was Billy Graham's father-in-law) set the tone of this discussion. The "sex revolution" developed because "modern man" did not recognize that God had "certain absolutes for sex" ("Sex in Christian Perspective" 1960). Yet, if modern man had forgotten these absolutes, Sherwood Wirt contended women were, in part, to blame. Their emancipation and their assertion of their sexuality broke from the past. Wirt's general concern was made specific by Carl Henry. Oral contraceptives ushered in a world that was different from that "known to biblical theology" ("Sex in Christian Perspective" 1960). The FDA had approved the first oral contraceptive in the United States in May of 1960, and it went on

9 Carl Henry, L. Nelson Bell, Frank Farrell, Sherwood Wirt, and David Kucharsky participated in the first discussion. Wirt was absent in the second. 
sale on 23 July 1960, just weeks before the panel discussion was published (Gibson 2015; Immerwahr 2019, pp. 248-51; Griffith 2017, p. 155). Fears about women's emancipation and sexual self-expression were firmly tied to the realities the pill promised.

If the pill allowed for sex without the risk of pregnancy, the more significant problem was that sex was being peddled everywhere. Echoing Sorokin, the editors lamented about increasingly sexualized media, literature, and advertising, and they fretted about ongoing challenges to anti-obscenity laws. They took heart in the fact that the Post Office was allowed to defend "the nation's morals" by removing obscenity from the mail ("Sex in Christian Perspective" 1960). Yet, the Post Office alone could not stop the saturation of sex into society. The courts themselves were in the process of redefining obscenity and making it easier to consume pornographic material (McGirr 2001, pp. 226-27). In any case, the editors did not believe that legislating morality was an option.

What could Christians do to reform the United States? For one, they could not return to a "Victorian view of sex" ("Sex in Christian Perspective" 1960). The editors, excepting Bell, did not oppose talk about sex. Rather, they disliked how talk about sex was proceeding. They believed that a return to a culture where sex was marked by "hushed attitude[s], the prudery, [and] the aggravated guilt feelings" of the Victorian era was unacceptable ("Sex in Christian Perspective" 1960). Evangelicals did, however, need to talk about sex in ways that conformed to the Bible. David Kucharksy argued that a biblically rooted sex education program needed to be developed, and the other editors agreed. Church sponsored sex education that placed sex in context and emphasized that it was "only a part of married life" could "challenge the commercial interests and mass media that publicize and glorify unchastity and incontinence" ("Sex in Christian Perspective" 1960).

Teaching young Christians about what the Bible had to say about sex was only a half measure though. Christians could talk about sex in "biblical" ways in the confines of the church, but this would not prevent young people from encountering secular discussions of sex outside of their churches' walls. The need to address depictions of sex in the media prompted a second panel discussion. The editors' wide-ranging discussion of the press's responsibility to talk about sex in morally permissive ways circled around a key question. Should Christians expect editors of secular periodicals to conform to Christians' expectations in the stories and advertisements they published? Yes and no. Editors should not be expected to display Christian virtue on each page of the paper, but they did need to recognize that licentious discussions of sex in the press would produce a "breakdown in morality" along with "sex obsession and moral laxity." If papers continued to allow sex to sell papers, a "new ethic" would develop ("The Press and Sex Morality" 1961).

As before, the editors returned to how sex could be "properly" talked about. To hide away or avoid these discussions was not satisfactory. After all, sex remained "one of life's deepest drives," and it needed to be discussed ("The Press and Sex Morality" 1961). Therefore, the press had an obligation to report on stories related to sex, but it needed to do so in morally responsible ways. To Henry, the distinction needed to be made between liberty and license. Liberty, in this case the freedom of the press, was intertwined with morality. If morality was lost, liberty became license, and license "leads to the demand for censorship" ("The Press and Sex Morality" 1961). The right of the free press was tied to moral responsibility, and the press was increasingly shirking its responsibilities. ${ }^{10}$ Bell's belief that a new and unbiblical ethic rooted in sexual permissiveness was gaining ground led the editors to argue that evangelicals needed to firmly challenge this ethic. To raise this challenge, they needed to go to the source of the sexual revolution-the college campus.

David L. McKenna, the former president of several Christian colleges and universities and (at the time of this writing) the president of Spring Arbor College, believed the center of the "revolutionary storm" in morals was to be found on college campuses (McKenna 1964). He argued that this revolution in morals could rightly be called a "sexplosion," and it

10 For editorials that expand on the editors' concerns about the press and obscenity, see ("Diagnosis is Not Enough" 1963; "Pornography in a Free Society" 1970). 
was creedal. Its doctrine was rooted in the belief that sex was freedom, security, fun, love, nothing, and status. All in all, this meant that sex and sexual pleasure were an end unto themselves. To have sex, and to have it often, gave meaning to life. McKenna was appalled by this new sexual ethic. He proposed a "plan for striking back" that hearkened to CT's call for a new kind of curricula in conservative Christian higher education (McKenna 1964). First and foremost, the Christian college needed to provide sex education rooted in a Christian perspective. This education could not emphasize sexual prudishness. Censuring discussions about sex would only make it more enticing. Rather, it needed to fight "freedom with Freedom," challenging the "Morals Revolution" with the emancipatory promise of spiritual redemption (McKenna 1964).

The editors of CT shared McKenna's diagnosis. The U.S. was on a slippery slide towards the "pervasive immorality ... of the ancient world" ("Facing the Tide of Obscenity" 1965). In order to arrest this slide, evangelicals and their religious allies-Catholics and Jews-needed to emphasize the importance of the seventh commandment: Thou shalt not commit adultery. Further, the editors again called for the "creation of an evangelical literature" that dealt as thoroughly with "love and sex ... as with the issues of life and death" ("Facing the Tide of Obscenity" 1965). A later editorial expanded on these concerns about the "new morality" ("The Debilitating Revolt" 1967). The editors contended that the most perilous feature of this new morality was its lack of absolutes. Absent absolutes, any sexual actor was able to determine what was right, and this disregard for "divine commandments ... encouraged disobedience of God" ("The Debilitating Revolt" 1967). To the editors, there was no doubt about the Bible's sexual ethic. It could be quickly summed up by looking at several key verses: Do not fornicate (1 Corinthians 6:18); do not commit adultery (Exodus 20:14); it was better to get married than to succumb to lust (1 Corinthians 7:9); husbands and wives should have sex with one another (1 Corinthians 7:3,5); and homosexuality was wrong (Jude 7) ("The Debilitating Revolt" 1967). These precepts, while foundational to sex manuals published by evangelicals from the 1970s until today, are by no means illustrative of how the Christians that adhered to them should have sex. The technical aspects of sex were still being taught in public schools, and evangelicals were worried that these programs did not align with biblical principles.

\section{Evangelicals and Sex Education}

Mary Calderone's Sex Information and Education Council of the United States (SIECUS) and its efforts to teach a comprehensive sex education program absent sectarian concerns spawned controversy (McGirr 2001, pp. 226-31). Unlike Billy James Hargis's Christian Crusade, CT did not peddle conspiracies about SIECUS particularly and sex education more broadly. ${ }^{11}$ Though, letters to the editor suggested that some readers of $C T$ were more closely aligned with Hargis ("Sex and the Christian Child" 1969). James Huffman, at the time a Ph.D. student in Japanese history, wrote an article that laid the groundwork for $C T^{\prime}$ 's coverage of sex education in public schools. Huffman's article was both a rebuke of "far right groups" (like the John Birch Society and Hargis's followers) that lied about SIECUS and a call for Christian sex education programs (Huffman 1969). He believed it was unsurprising that sex education would be taught in schools because parents and churches were failing to teach young people about sex, and he contended that criticizing sex education programs without offering Christian alternatives would not suffice. The Bible, after all, "has much to say about sex," and it needed to be closely read in order to develop an authority-laden and biblical sex education program, one that could be taught by the church (Huffman 1969).

Editor-in-chief Harold Lindsell agreed with portions of Huffman's analysis. As one point of divergence, he was less congratulatory towards SIECUS. While he acknowledged that it was often treated unfairly, he believed its utility was limited because of whom it was associated with—sexologists and periodicals that Lindsell believed promoted sex for

11 Calderone herself appreciated CT's coverage of SIECUS. See Calderone's letter in ("Sex and the Christian Child" 1969). 
pleasure (Lindsell 1970). Yet, Lindsell did agree with Huffman's core ideas. He agreed that parents were "delegating" their parental role to schools to avoid the "embarrassing duty" of teaching their children about sex (Lindsell 1970). Lindsell also agreed that churches needed to develop sex ed programs. His editorial is significant because, unlike previous articles and editorials that argued for the development of a Christian sex education program with biblical references or platitudes, Lindsell began to outline a plan.

Any talk about sex needed to treat "the whole area of love" (Lindsell 1970). By this, Lindsell meant that sex was only one part of a loving marital relationship, and it needed to be placed in proper context. Furthermore, technical aspects of sex should be taught to only mature students (i.e., those in their late teens or those preparing for marriage) in sex-separated classes. Most importantly, "sex cannot be presented in a moral vacuum" (Lindsell 1970). Anyone who believed that bringing Christian ethics into schools contradicted the First Amendment failed to realize that morality was already being taught in schools. "Relativist ethics" were, after all, a comparable religious "world view," and they contradicted the absolute moral framework of the Bible (Lindsell 1970). In the end, Lindsell suggested Christians could do three things about sex education: "get involved in their local schools," teach their children about sex at home, and encourage evangelical publishers to produce biblical sex ed curricula (Lindsell 1970). By the middle of the 1970s, the third step of Lindsell's plan would be satisfied, and the production of an evangelical sex ed program had the potential to fulfill the first two goals. With it, parents could provide alternative models for their schools to follow and have reference manuals to help them discuss a biblical view of sex with their children.

The sex and marriage manuals published by conservative Protestants in the 1970s (and after) largely realized CT's editors' calls for a distinctly Christian sex education curriculum. Editors and contributors to the magazine were keenly aware of conservative Protestant books that discussed sex. In a group review of a new crop of Christian sex manuals, C.E. Cerling Jr. (a minister of education at a Baptist church in Saginaw, MI) affirmed that conservative Protestants were not declaring "thou shalt not's" when it came to sex (Cerling 1976). Rather, they preached that "thou shalt enjoy thyself as God intended" (Cerling 1976). He thought this sex positivity was welcome after a period when nonChristians alone spoke of sexual pleasure.

Christian books were noteworthy because they spoke clearly about sexual pleasure while emphasizing that sex was "more than a physical union," and this meant that Christians needed to wait until marriage to have sex (Cerling 1976). Then, and only then, could the physical, relational, and spiritual purpose of sex be realized. Cerling's review also spoke candidly about outercourse. Unlike some of the books he reviewed (especially Sex for Christians by Lewis Smedes), he believed that masturbation and petting were a gateway to deeper lust and condemned these activities.

Cerling continued his analysis of sex and marriage manuals in a later edition of $C T$ when he reviewed The Act of Marriage. He was happy to see that The Act of Marriage gave ample space to anatomy, physiology, and sexual techniques. Not only did the LaHayes root their book in Christian principles, but they recognized the limits of biblical data in certain sexual matters-like oral sex-while giving their "informed Christian opinion" on whether it was right or wrong (Cerling 1977). (They concluded it was wrong.) Amid the many sex resources that were now being published in conservative Protestantism, the LaHayes' stood out to Cerling because their conservative bona fides were well established.

\section{4. "The Year of Male and Female"}

In a 1977 summation of the "new candor [about sexuality] in evangelical books," CT's associate editor, Donald Tinder, reviewed a number of these new books (Tinder 1977b, "A New Candor"). If 1976 was the year of the evangelical for the mainstream press, Tinder believed that it was "the year of male and female" for conservative Protestant book publishers (Tinder 1977b, "A New Candor"). Moreover, he also argued that the publishing boom of 1976 was prompted by three "controversial" books about women's 
roles-Morgan's The Total Woman, Letha Scanzoni and Nancy Hardesty's All We're Meant to Be: A Biblical Approach to Women's Liberation, and Paul Jewett's God as Male and Female.

Tinder's review reaffirmed that the decades long push by $C T$ for a comprehensive Christian sex education program was realized by the mid 1970s. He rattled off a half dozen books that discussed sex with an eye for the theological and the technical. Of these, The Act of Marriage was "the biggest breakthrough" (Tinder 1977b, "A New Candor"). Not only did it discuss sex in biblically acceptable ways, but Tinder believed that it broke new ground by avoiding the slippage into the "perversion" of non-Christian sex books (Tinder 1977a, "Choice Evangelical Books,"). In celebrating The Act of Marriage as a conservative Christian alternative to secular sex manuals, Tinder hinted at evangelical engagement with the sexual component of the self-help movement of the 1970s. ${ }^{12}$ If books like Alex Comfort's The Joy of Sex were a how to guide for how to have sex regardless of one's marital status, The Act of Marriage stood in the gap as a "Christian counterpart" to Comfort's acceptance of sex outside of marriage (Tinder 1976). Yet, sex manuals with a thoroughly patriarchal tone, such as The Act of Marriage, were not solely responsible for making 1976 the year of male and female. In particular, Tinder's belief that books like All We're Meant to Be spurred books like The Act of Marriage signaled that conservative Protestantism's emergent sexual ethics were intended to clearly dictate men and women's distinct marital roles in a moment when Christian feminists challenged a patriarchal reading of the Bible.

Released in 1974, All We're Meant to Be was a feminist text. Scanzoni and Hardesty believed that the Bible held a transcendent view of the "male female polarity," which meant that there was no "sexual distinctiveness insofar as the realm of the sacred is concerned" (Scanzoni and Hardesty 1975, p. 14). Even though it challenged the patriarchal and complementarian ethos that many writers of $C T$ advanced, the magazine endorsed All We're Meant to Be as "one of the finest books to come out on the controversial subject of women's liberation" (Scanzoni and Hardesty 1975, back cover; "Book of the Year, Topic of the Year" 1975). This endorsement is even more striking given that Scanzoni and Hardesty supported birth control (including vasectomies and tubal ligations) for couples uninterested in having children, and they also supported abortion in cases where a family was unable to raise a(nother) child (Scanzoni and Hardesty 1975, pp. 140-44). Furthermore, Scanzoni and Hardesty talked about sexuality outside of the context of marriage. They believed that singleness was not, as it was sometimes presented, inferior to marriage (Scanzoni and Hardesty 1975, p. 146). Moreover, the single Christian did not need to be wholly sexually inactive. Scanzoni and Hardesty contended that masturbation and other forms of sexual self-care could be good (Scanzoni and Hardesty 1975, pp. 152-59). What of the single Christian who did have sex outside of marriage? God stood "ready at all times to forgive those who confess their sins and seek his healing" (Scanzoni and Hardesty 1975, p. 157).

Endorsements aside, All We're Meant to Be was not accepted by the readers or editors of $C T$, and they worried about the biblical veracity of the book. One reader was "puzzled and dismayed" that $C T$ would recommend a book that supposed feminism was biblical ("Surprisingly Healthy" 1976). His complaint was echoed by editor-in-chief Harold Lindsell. Lindsell contended that egalitarianism in marriage and in the church lacked a strong biblical basis. Though, he insisted that he would accept an egalitarian argument that did not "denigrate scripture" (Lindsell 1976). This challenge to inerrancy was, as Lindsell understood it, particularly pronounced amid debates over the passage of the Equal Rights Amendment.

This debate over All We're Meant to Be could easily be read as just another intraevangelical feud about biblical interpretation (and it was.) However, it was more than that, because this debate spilled over into conservative Protestants' sociopolitical activism. In reading

12 For a succinct explanation of secular sex manuals and their relationship to the self-help movement, see, Anna E. Ward, "Sex and the Me Decade: Sex and Dating Advice Literature of the 1970s," Women's Studies Quarterly 43, no. 3-4 (Ward 2015), pp. 120-36. While evangelical writers in the pages of $C T$ opposed sex manuals like The Joy of Sex because they did not condemn sex outside of marriage, it is worth noting that Comfort was not as radical as many authors presumed. He concluded The Joy of Sex by affirming that monogamy and heterosexuality were "normal." See, DeRogatis (2005), "What Would Jesus Do?," p. 106. 
a feminist text as one of the impetuses for the emergence of a sex manual genre within evangelicalism, Tinder revealed that talk about sex was never far from talk about gender orders and the "biblically" prescribed roles of men and women. Therefore, even as sex manuals increasingly satisfied an evangelical craving for conservative Protestant sex education curricula, talk about sex became an obsession for another reason. It allowed conservative Protestants to establish tenets that breached the bedroom. Conservative Protestants took to the polls and the streets to lobby for the sexual distinctiveness of men and women, male headship, heterosexuality, and monogamy. These values were embedded in sex and marriage manuals, and they produced an evangelicalism that was deeply concerned about sexual morality and its wider implications as an (if not the) indicator of social health and order.

\section{Conclusions}

Decades of evangelical talk about how to combat a sex obsessed culture ironically produced an evangelicalism that is obsessed with sex and its sociocultural effects. Historian Janice Irvine has demonstrated that battles over sex education were a key component in the development of the religious right, and, while it would be difficult to see sex as the factor on which the religious right coalesced, it has increasingly played an outsized role in evangelical politics. Indeed, if evangelicals lamented the ubiquity of talk about sex, they contributed to a United States where "sex was everywhere spoken" (Irvine 2002, p. 61; Jenkins 2017). Christianity Today demonstrates that evangelical efforts to speak about sex in biblically acceptable ways was not wholly repressive and not merely reactionary. Rather, conservative Protestants generated an ethic that was presented as an age old and absolute truth rather than historically rooted in concerns from the 1960s and 1970s. These concerns were exemplified by $C T^{\prime}$ 's editors and their fear that evangelical Christians could not substantively discuss sexuality in their own terms.

Throughout the 1960s, the editors and contributors of CT cried out for Christian sexual education material that could help them navigate the wilderness that changes in obscenity laws, the development of the birth control pill, the sexual revolution on college campuses, and the growth of sex education programs in public schools produced. These cries were pronounced because CT's staff, and fellow conservative Protestants, believed that sexual morality was intimately linked with social health. If the United States became a society that happily peddled licentiousness and obscenity, it would collapse. Conservative Christians believed they had a responsibility to find new ways to talk about sex that were biblical and morally upright. By the middle of the 1970s, CT believed that its particular brand of conservative Protestantism had done as much. A publishing boom of sex manuals written by bona fide conservative Protestants gave parents, pastors, and Christian educators alternative materials to teach young adults about sex. These manuals were never simply about sex. They were marriage manuals that complemented conservative Protestants' firm belief that marital relationships were defined by heterosexuality, monogamy, and male headship.

That final point-male headship—bears emphasizing. Donald Tinder's recognition that conservative Protestant sex manuals were inspired by challenges to patriarchy and a conservative gender order marked by masculinity is significant. This point exemplifies what historians Kristin Kobes Du Mez and Beth Allison Barr have made clear about evangelicalism in the United States (Du Mez 2020a; Barr 2019). Namely, evangelicals' commitment to patriarchy and masculinity is foundational to the movement and can trump other stated beliefs. Sex manuals not only produced a new evangelical sexual ethic, but they reinforced a gendered order wherein men's sins could be forgiven, their many appetites could be sated, and their whims could be catered to. Women should not, as Marabel Morgan made clear, nag their husbands or try to change them. Instead, women needed to change their own behaviors and accept their husbands to make their husbands happy and keep them emotionally and sexually interested (Morgan 1973, pp. 50-53). In this 
schema, patriarchy and deference to masculinity has become a cornerstone of conservative Protestantism's post-1960s sexual ethics.

Funding: This research received no external funding.

Institutional Review Board Statement: Not applicable.

Informed Consent Statement: Not applicable.

Data Availability Statement: Primary source data was obtained from Christianity Today and are available at https://www.christianitytoday.com/ct/archives/ (accessed on 9 February 2021) with a paid subscription.

Acknowledgments: Special thanks to Molly Worthen, John Hawthorne, and Mark Edwards for reading early drafts and pushing me to think more clearly about the sources and argument. Edwards told me about this special issue and sparked my interest in U.S. religious history when I was an undergraduate student. His immense intellectual and personal generosity and his abiding interest in his students' work long after they have sat in one of his classrooms has always impressed me. He exemplifies what it means to be both an historian and a teacher. Thanks also to James Mitchell and Bruce W. Crane. Their comments helped me think about future avenues for research and added levity to the editing process. I am also indebted to Aunt Marge, who somehow manages to find the time to both make the world a better place and provide invaluable writing advice. Last, but certainly not least, Greg Lunt reads almost every word I write. I am forever grateful that he has always taken my ideas seriously. Thanks Dad!

Conflicts of Interest: The author declares no conflict of interest.

\section{References}

"Book of the Year, Topic of the Year". 1975. Book of the Year, Topic of the Year. Christianity Today. November 21. Available online: https:/ / www.christianitytoday.com/ct/1975/november-21/editorials-and-how-are-things-at-home.html (accessed on 18 December 2020).

“Diagnosis is Not Enough". 1963. Diagnosis is Not Enough. Christianity Today. October 25. Available online: https://www. christianitytoday.com/ct/1963/october-25/editorials-diagnosis-is-not-enough.html (accessed on 7 December 2020).

“Evangelical Advance". 1960. Evangelical Advance: Do We Need a Christian University? Christianity Today. May 9. Available online: https:/ / www.christianitytoday.com/ct/1960/may-9/evangelical-advance-do-we-need-christian-university.html (accessed on 8 December 2020).

"Facing the Tide of Obscenity". 1965. Facing the Tide of Obscenity. Christianity Today. April 9. Available online: https://www. christianitytoday.com/ct/1965/april-9/facing-tide-of-obscenity.html (accessed on 7 December 2020).

“Marabel Morgan: 'Preferring One Another'”. 1976. Marabel Morgan: 'Preferring One Another'. Christianity Today. September 10. Available online: https:/ / www.christianitytoday.com/ct/1976/september-10/preferring-one-another.html (accessed on 10 December 2020).

"Pornography in a Free Society". 1970. Pornography in a Free Society. Christianity Today. May 22. Available online: https: //www.christianitytoday.com/ct/1970/may-22/pornography-in-free-society.html (accessed on 7 December 2020).

"Sex and the Christian Child". 1969. Sex and the Christian Child. Christianity Today. October 24. Available online: https://www. christianitytoday.com/ct/1969/october-24/eutychus-and-his-kin.html (accessed on 7 December 2020).

"Sex in Christian Perspective". 1960. Sex in Christian Perspective. Christianity Today. July 4. Available online: https://www. christianitytoday.com/ct/1960/july-19/sex-in-christian-perspective.html (accessed on 7 December 2020).

“Surprisingly Healthy". 1976. Surprisingly Healthy. Christianity Today. January 2. Available online: https:/ / www.christianitytoday. com/ct/1976/january-2/eutychus-and-his-kin.html (accessed on 11 December 2020).

“The Debilitating Revolt". 1967. The Debilitating Revolt. Christianity Today. July 21. Available online: https://www.christianitytoday. com/ct/channel/utilities / print.html?type=article\&id=154423 (accessed on 7 December 2020).

“The Evangelical Witness". 1956. The Evangelical Witness in a Modern Medium. Christianity Today. October 15. Available online: https: //www.christianitytoday.com/ct/1956/october-15/evangelical-witness-in-modern-medium.html (accessed on 15 December 2020).

“The Press and Sex Morality". 1961. The Press and Sex Morality. Christianity Today. January 30. Available online: https://www. christianitytoday.com/ct/1961/january-30/editorials-press-and-sex-morality.html (accessed on 7 December 2020).

“What of Racial Intermarriage?". 1963. What of Racial Intermarriage? Christianity Today. October 11. Available online: https: //www.christianitytoday.com/ct/1963/october-11/editorials.html (accessed on 7 December 2020).

Bailey, Beth. 1994. Sexual Revolutions. In The Sixties from Memory to History. Edited by David Farber. Chapel Hill: The University of North Carolina Press, pp. 235-62.

Bailey, Beth. 1999. Sex in the Heartland. Cambridge: Harvard University Press. 
Barr, Beth Allison. 2019. What If Biblical Womanhood Isn't Biblical? The Anxious Bench. October 2. Available online: https: //www.patheos.com/blogs/anxiousbench/2019/10/what-if-biblical-womanhood-isnt-biblical/ (accessed on 4 January 2021).

Botham, Fay. 2009. God Almighty Created the Races: Christianity, Interracial Marriage, E American Law. Chapel Hill: The University of North Carolina Press.

Cerling, C. E., Jr. 1976. Book Briefs: October 8, 1976. Christianity Today. October 8. Available online: https://www.christianitytoday. com/ct/1976/october-8/books.html (accessed on 29 December 2020).

Cerling, C. E., Jr. 1977. Book Briefs: March 18, 1977. Christianity Today. March 18. Available online: https:/ / www.christianitytoday. com/ct/1977/march-18/books.html (accessed on 29 December 2020).

Dailey, Jane. 2004. Sex, Segregation, and the Sacred after Brown. The Journal of American History 91: 119-44. [CrossRef]

de Grazia, Victoria. 2005. Irresistible Empire: America's Advance through 20th Century Europe. Cambridge: Belknap Press.

DeRogatis, Amy. 2005. What Would Jesus Do?: Sexuality and Salvation in Protestant Evangelical Sex Manuals, 1950s to the Present. The American Society of Church History 74: 97-137. [CrossRef]

DeRogatis, Amy. 2015. Saving Sex: Sexuality and Salvation in American Evangelicalism. New York: Oxford University Press.

Dowland, Seth. 2015. Family Values and the Rise of the Christian Right. Philadelphia: University of Pennsylvania Press.

Du Mez, Kristin Kobes. 2020a. Jesus and John Wayne: How Evangelicals Corrupted a Faith and Fractured a Nation. New York: Liveright.

Du Mez, Kristin Kobes. 2020b. Review of Who Is an Evangelical? American Religion 2: 201-4.

Gibson, Megan. 2015. One Factor that Kept the Women of 1960 away from Birth Control Pills: Cost. Time. June 23. Available online: https:/ / time.com/3929971/enovid-the-pill/ (accessed on 17 December 2020).

Griffith, R. Marie. 2017. Moral Combat: How Sex Divided American Christians \& Fractured American Politics. New York: Basic Books.

Hall, Simon. 2008. Protest Movements in the 1970s: The Long 1960s. Journal of Contemporary History 43: 655-72. [CrossRef]

Hall, Simon. 2011. American Patriotism, American Protest: Social Movements Since the Sixties. Philadelphia: University of Pennsylvania Press.

Hartman, Andrew. 2016. A War for the Soul of America: A History of the Culture Wars. Chicago: University of Chicago Press.

Hemmer, Nicole. 2016. Messengers of the Right: Conservative Media and the Transformation of American Politics. Philadelphia: University of Pennsylvania Press.

Houck, Davis W., and David E. Dixon, eds. 2014. Rhetoric, Religion, and the Civil Rights Movement, 1954-1965. Waco: Baylor University Press, vol. 2.

Huffman, James. 1969. Sex Education in Public Schools. Christianity Today. September 26. Available online: https://www. christianitytoday.com/ct/1969/september-26/sex-education-in-public-schools.html (accessed on 9 December 2020).

Immerwahr, Daniel. 2019. How to Hide an Empire: A History of the Greater United States. New York: Picador.

Irvine, Janice. 2002. Talk about Sex: The Battles over Sex Education in the United States. Berkeley: University of California Press.

Jenkins, Jack. 2017. Are Evangelicals Inventing a New Kind of Christianity That's All about Sex? ThinkProgress. September 2. Available online: https: / / archive.thinkprogress.org/are-evangelicals-inventing-a-new-form-of-christianity-all-about-sex-46ff64454c8f/ (accessed on 3 December 2020).

Kidd, Thomas. 2019. Who Is an Evangelical?: The History of a Movement in Crisis. New Haven: Yale University Press.

Laats, Adam. 2018. Fundamentalist U: Keeping the Faith in Higher Education. New York: Oxford University Press.

Lindsell, Harold. 1970. Sex, SIECUS, and the Schools. Christianity Today. January 30. Available online: https:/ /www.christianitytoday. com/ct/1970/january-30/sex-siecus-and-schools.html (accessed on 9 December 2020).

Lindsell, Harold. 1976. Egalitarianism and Scriptural Infallibility. Christianity Today. March 26. Available online: https://www. christianitytoday.com/ct/channel/utilities/print.html?type=article\&id=145603 (accessed on 11 December 2020).

McGirr, Lisa. 2001. Suburban Warriors: The Origins of the New American Right. Princeton: Princeton University Press.

McKenna, David L. 1964. The Morals Revolution and the Christian College. Christianity Today. June 4. Available online: https: / / www.christianitytoday.com/ct/1964/june-19/morals-revolution-and-christian-college.html. (accessed on 7 December 2020).

Morgan, Marabel. 1973. The Total Woman. Old Tappan: Fleming H. Revell Company.

Noll, Mark A., David W. Bebbington, and George Marsden, eds. 2019. Evangelicals: Who They Have Been, Are Now, and Could Be. Grand Rapids: Wm. B. Eerdmans Publishing Co.

Ockenga, Harold John. 1957. Facing Decay. Christianity Today. March 4. Available online: https://www.christianitytoday.com/ct/1957 /march-4/books-in-review.html (accessed on 16 December 2020).

Scanzoni, Letha, and Nancy Hardesty. 1975. All We're Meant to Be: A Biblical Approach to Women's Liberation. Waco: Word Books.

Self, Robert. 2012. All in the Family: The Realignment of American Democracy Since the 1960s. New York: Hill and Wang.

Sorokin, Pitirim A. 1956. The American Sex Revolution. Boston: Porter Sargent Publisher.

Sorokin, Pitirim A. 1959. Demoralization of Youth: Open Germs and Hidden Viruses. Christianity Today. July 6. Available online: https:/ / www.christianitytoday.com/ct/1959/july-6/demoralization-of-youth-open-germs-and-hidden-viruses.html (accessed on 16 December 2020).

Sorokin, Pitirim A. 1960. The Depth of the Crisis: American Sex Morality Today. Christianity Today. July 4. Available online: https: //www.christianitytoday.com/ct/1960/july-19/depth-of-crisis-american-sex-morality-today.html (accessed on 7 December 2020).

Sorokin, Pitirim A. 1963. A Long Journey: The Autobiography of Pitirim A. Sorokin. New Haven: College and University Press. 
Sorokin, Sergei P. 2017. Life with Pitirim Sorokin: A Younger Son's Perspective. PitirimSorokin.com. December 6. Available online: https://pitirimsorokin.com/2017/12/06/sergei-p-sorokin-life-with-pitirim-sorokin-a-younger-sons-perspective/ (accessed on 1 February 2021).

Tinder, Donald. 1976. Bible Study, Peace on Earth Handbook, and Other Approaches. Christianity Today. September 10. Available online: https://www.christianitytoday.com/ct/1976/september-10/bible-study-peace-on-earth-handbook-and-otherapproaches.html (accessed on 10 December 2020).

Tinder, Donald. 1977a. Choice Evangelical Books. Christianity Today. March 18. Available online: https:/ /www.christianitytoday.com/ ct/1977/march-18/choice-evangelical-books.html (accessed on 10 December 2020).

Tinder, Donald. 1977b. Sexuality: A New Candor in Evangelical Books. Christianity Today. March 18. Available online: https: //www.christianitytoday.com/ct/1977/march-18/sexuality-new-candor-in-evangelical-books.html (accessed on 10 December 2020).

Tisby, Jemar. 2019. Are Black Christians Evangelicals? In Evangelicals: Who They Have Been, Are Now, and Could Be. Edited by Mark Noll, David W. Bebbington and George Marsden. Grand Rapids: Wm. B. Eerdmans Publishing Company, pp. 262-72.

Vaca, Daniel. 2019. Evangelicals Incorporated: Books and the Business of Religion in America. Cambridge: Harvard University Press.

Ward, Anna E. 2015. Sex and the Me Decade: Sex and Dating Advice Literature of the 1970s. Women's Studies Quarterly 43: 120-36. [CrossRef]

Worthen, Molly. 2014. Apostles of Reason: The Crisis of Authority in American Evangelicalism. New York: Oxford University Press.

Young, Neil. 2018. Fascinating and Happy: Mormon Women, the LDS Church, and the Politics of Sexual Conservatism. In Devotions and Desires: Histories of Sexuality and Religion in the Twentieth Century United States. Edited by Gillian Frank, Heather R. White and Bethany Moreton. Chapel Hill: The University of North Carolina Press, pp. 193-213. 